University of Nebraska - Lincoln

DigitalCommons@University of Nebraska - Lincoln

U.S. Navy Research

U.S. Department of Defense

2007

\title{
Diversifying Biological Fuel Cell Designs by Use of Nanoporous Filters
}

Justin C. Biffinger

US Naval Research Laboratory, justin.biffinger@nrl.navy.mil

Ricky Ray

Naval Research Laboratory

Brenda Little

Naval Research Laboratory, blittle@nrlssc.navy.mil

Bradley R. Ringeisen

Naval Research Laboratory, Bradley.ringeisen@nrl.navy.mil

Follow this and additional works at: https://digitalcommons.unl.edu/usnavyresearch

Part of the Operations Research, Systems Engineering and Industrial Engineering Commons

Biffinger, Justin C.; Ray, Ricky; Little, Brenda; and Ringeisen, Bradley R., "Diversifying Biological Fuel Cell Designs by Use of Nanoporous Filters" (2007). U.S. Navy Research. 18.

https://digitalcommons.unl.edu/usnavyresearch/18

This Article is brought to you for free and open access by the U.S. Department of Defense at DigitalCommons@University of Nebraska - Lincoln. It has been accepted for inclusion in U.S. Navy Research by an authorized administrator of DigitalCommons@University of Nebraska - Lincoln. 


\section{Diversifying Biological Fuel Cell Designs by Use of Nanoporous Filters}

\author{
JUSTIN C. BIFFINGER, ${ }^{\dagger}$ RICKY RAY, ～$^{\ddagger}$ \\ B RENDA LITTLE, ${ }^{\ddagger}$ AND \\ B R A D LEY R. RINGEISEN*, \\ Chemistry Division, Naval Research Laboratory, \\ 4555 Overlook Avenue, SW, Washington, District of \\ Columbia 20375, and Oceanography Division, Naval Research \\ Laboratory, Building 1009, John C. Stennis Space Center, \\ Mississippi 39529
}

The use of proton exchange membranes (PEMs) in biological fuel cells limits the diversity of novel designs for increasing output power or enabling autonomous function in unique environments. Here we show that selected nanoporous polymer filters (nylon, cellulose, or polycarbonate) can be used effectively in place of PEMs in a miniature microbial fuel cell (mini-MFC, device cross-section $2 \mathrm{~cm}^{2}$ ), generating a power density of $16 \mathrm{~W} / \mathrm{m}^{3}$ with an uncoated graphite felt oxygen reduction reaction (ORR) cathode. The incorporation of polycarbonate or nylon membranes into biological fuel cell designs produced comparable power and durability to Nafion-117 membranes. Also, high power densities for novel larger $\left(5 \mathrm{~cm}^{3}\right.$ anode volume, $\left.0.6 \mathrm{~W} / \mathrm{m}^{3}\right)$ and smaller $\left(0.025 \mathrm{~cm}^{3}\right.$ projected geometric volume, average power density $10 \mathrm{~W} / \mathrm{m}^{3}$ ) chamberless and pumpless microbial fuel cells were observed. As an additional benefit, the nanoporous membranes isolated the anode from invading natural bacteria, increasing the potential applications for MFCs beyond aquatic sediment environments. This work is a practical solution for decreasing the cost of biological fuel cells while incorporating new features for powering long-term autonomous devices.

\section{Introduction}

Microbial fuel cells (MFCs) are a subset of biological fuel cells that show particular promise for powering long-duration sensors from indigenous nutrients $(1,2)$. Polymer electrolyte membranes (also defined as proton exchange membranes, PEMs) commonly used within the basic designs of these devices were first used in $\mathrm{H}_{2} / \mathrm{O}_{2}$ fuel cells during the Gemini space missions in the 1960s (3). Over the next 40 years, PEM fuel cells have become one of the most common designs for converting fuels such as hydrogen, methanol, or formic acid into DC electricity (4). In recent years, biological fuel cells with PEMs have gained broad interest because they operate under conditions and with fuels that are not compatible with mainstream $\mathrm{H}_{2} / \mathrm{O}_{2}$ fuel cell technology (5). Specifically, MFCs show room-temperature activity at neutral $\mathrm{pH}$ with a wide variety of alternative fuels ranging from elemental sulfur up to complex carbohydrates $(5,6)$. MFCs are able to operate under these conditions because they incorporate the me-

\footnotetext{
* Corresponding author phone: 202-767-0719; fax: 202-404-8119; e-mail: Bradley.Ringeisen@nrl.navy.mil.

${ }^{\dagger}$ Chemistry Division, Naval Research Laboratory.

‡ Oceanography Division, Naval Research Laboratory.
}

tabolism of whole organisms to generate electricity either directly (i.e., metal-reducing bacteria such as Geobacter sp. (1), Rhodoferax sp. (7), and with the aid of secreted mediators in the Shewanella sp. $(8,9)$ ) or indirectly (biological fermentation of carbon sources to hydrogen with Escherichia sp. or Clostridium sp.) from indigenous nutrients $(10,11)$.

Recent work suggests that power can be generated with significant oxygen in the anolyte when three-dimensional (3D) electrodes and a miniature MFC design (12) are used with the versatile microbe Shewanella oneidensis DSP10 [capable of both anaerobic and aerobic metabolism (13)], potentially expanding the role of MFCs to function in more diverse regions (i.e., water column, air/water interface). The advantages of working in aerobic aquatic environments include a more efficient cathodic ORR (due to increased oxygen concentration) and significantly higher operating temperatures (up to $9 \%$ increased current output from MFCs for a $12{ }^{\circ} \mathrm{C}$ rise in temperature) (14). Conversely, aerobic aquatic environments are inhabited by a diverse population of bacteria that could potentially compete with biofilm formation on the anode and prevent long-term and sustainable current production. In addition, increased oxygen concentration at the anode will result in competitive electron scavenging, which will reduce current output. Incorporating nanoporous filters (also termed nanoporous membranes) into MFC designs will address each of these issues. Specifically, the membranes could be used to sequester/isolate the desired metal-reducing bacteria to prevent contamination and lead to previously unattainable designs that limit oxygen diffusion to the anode.

Standard approaches to designing biological fuel cells are still based on the ideas and materials of the traditional fuel cell community, with the most common devices consisting of two chambers separated by a cation-selective membrane. For example, Nafion is selective for osmotically transporting protons and other small cations across the membrane, while limiting the crossover of hydrogen or oxygen gas between the chambers. In a standard $\mathrm{H}_{2} / \mathrm{O}_{2}$ PEMFC, the Nafion membrane can be considered as a nonelectrically conducting electrolyte between the two electrodes that selectively transfers protons to the cathode to balance the charge that is generated from the anodic reaction. However, the stark difference in standard operating conditions for a $\mathrm{H}_{2} / \mathrm{O}_{2}$ PEMFC compared to biological fuel cells (neutral $\mathrm{pH}$ with competitive cations) suggests that the high selectivity of the membrane might be eliminated altogether with minimal loss in current. The selectivity governed by the membrane in biological PEMFCs is established by the catalysts used rather than the membrane itself. In the case of MFCs, the microbes are highly adaptable and enable operation of MFCs in the presence of a variety of fuels. Contrary to this, inorganic catalysts cannot adapt to fuel crossover between the cathode and anode chambers. Therefore, membranes with more general transport properties than Nafion could be advantageous and used effectively in biological fuel cells.

There has been some work on alternative MFC designs to the classic two-chamber system using PEMs in the literature. The pioneering work of Tender et al. (1) showed that naturally occurring metal-reducing bacteria can be utilized to generate a power density of $10-20 \mathrm{~mW} / \mathrm{m}^{2}$ with only anaerobic sediment and the natural oxygen gradient (sediment/seawater interface) creating the separation between the anode and cathode. A smaller laboratory membraneless single-chamber device has also been fabricated, but bacterial colonization of the cathode with time complicates analysis and may prevent long-term function (15). 


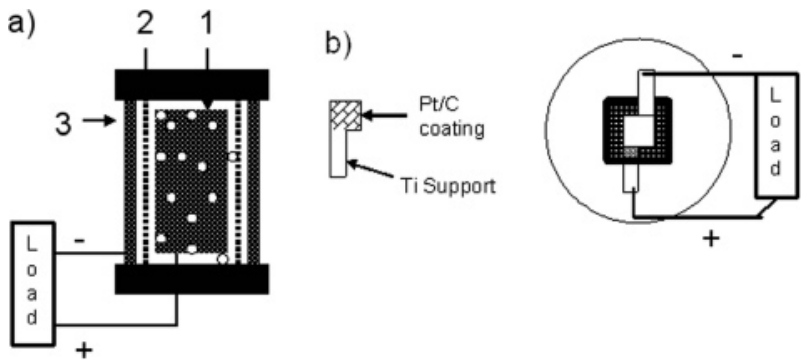

FIGURE 1. Schematic representations of the chamberless MFCs. (a) Cross-section of the dialysis-tube MFC with (1) GF anode with DSP10, (2) regenerated cellulose dialysis tube, and (3) GF cathode. (b) Micro-MFC design.

Finally, another single-chamber device has been fabricated by use of a relatively thick $(1 \mathrm{~mm})$ microporous porcelain septum to replace the traditional cationic membrane of a two-chamber fuel cell (16). We report the first systematic investigation of using thin $(20-50 \mu \mathrm{m})$, disposable $(\$ 0.02 /$ $\mathrm{cm}^{2}$ ) nanoporous filters/membranes to replace Nafion, leading to MFCs with novel passive diffusion properties necessary for real-time deployment in areas other than anaerobic sediment or sludge.

\section{Materials and Methods}

Bacterial Culture Conditions. The DSP10 strain of Shewanella oneidensis was grown aerobically in a $50 \mathrm{~mL}$ Erlenmeyer flask in Luria-Bertani (LB) broth (Difco Laboratories, Detriot, MI). The culture was incubated at $25^{\circ} \mathrm{C}$ for at least 4 days with shaking in air at $100 \mathrm{rpm}$. Cell counts ranged from $1 \times 10^{8}$ to $5 \times 10^{8}$ cells $/ \mathrm{mL}$, as determined by plating on LB/agar after serial dilution.

Fuel Cell Assembly and Operation: (1) Mini-MFC. The general dimensions and setup for the mini-MFC apparatus were described previously (17). The electrodes used within the fuel cell chambers were uncoated, low-density graphite felt $\left(0.13 \mathrm{~g}\right.$, Electrosynthesis Co., Lancaster, NY; $0.47 \mathrm{~m}^{2} / \mathrm{g}$ ) and were connected with titanium wires to an external load. The volume of each electrode chamber was $1.2 \mathrm{~cm}^{3}$ with 2 $\mathrm{cm}^{2}$ cross-sections. The anode and cathode chambers were separated by either regenerated cellulose (Fisherbrand, 12 000-14 000 Da, $20 \mu \mathrm{m}$ wall thickness), cellulose nitrate (Millipore, $0.2 \mu \mathrm{m}$ pore size, $125 \mu \mathrm{m}$ thickness), polycarbonate (Millipore, GTTP, $0.2 \mu \mathrm{m}$ pore size, $20 \mu \mathrm{m}$ thickness), nylon (Whatman, $0.2 \mu \mathrm{m}$ pore size, $20 \mu \mathrm{m}$ thickness), or Nafion117 (The Fuel Cell Store). The anolyte and catholyte were passed through the chambers at a flow rate of $1-4 \mathrm{~mL} / \mathrm{min}$ by use of a peristaltic pump. The catholyte was a $0.45 \mu \mathrm{m}$ filtered and aerated (bubbled) $100 \mathrm{mM}$ phosphate buffer ( $\mathrm{pH}$ 7.2) with uncoated GF electrodes. The influent level of dissolved oxygen in the catholyte and anolyte was measured at $8-9 \mathrm{ppm}$ and $<1 \mathrm{ppm}$, respectively, throughout the experiments (WPI, Sarasota, FL, ISO2 dissolved oxygen meter).

(2) Dialysis-Tube MFC. A schematic diagram of the dialysis-tube MFC is shown in Figure 1a. A $5 \mathrm{~cm}$ section of a $25 \mathrm{~mm}$ wide dialysis tube (regenerated cellulose) was autoclaved in $18 \mathrm{M} \Omega$ water at $121^{\circ} \mathrm{C}$ for $10 \mathrm{~min}$. The dialysis bag was clamped in a laminar flow hood with standard dialysis bag clips, and $0.48 \mathrm{~g}$ of autoclaved graphite felt connected with titanium wire was placed inside the tube. The tube was then entirely filled with $5 \mathrm{~mL}$ of a DSP 10 culture $\left(10^{8}\right.$ cells/ $\mathrm{mL}$ ) in LB broth and $15 \mathrm{mM}$ sodium lactate. The anode chamber was then sealed with a clip on the opposite side. A graphite felt cathode $(0.99 \mathrm{~g})$ was wrapped around the dialysis tube, secured with two plastic ties, and connected with titanium wire. The whole apparatus was then submerged in a sterile jar filled with $100 \mathrm{~mL}$ of minimal medium (18).
The jar lid had three holes, two of which were for the anode and cathode leads, while the third was used to insert an aeration (bubbling) tube. Sodium lactate $(10-30 \mathrm{mM})$ was added to the minimal media as fuel.

(3) Micro-MFC. A schematic diagram of the micro-MFC device is shown in Figure $1 \mathrm{~b}$. Two titanium foil flags (dimensions $5 \times 9 \mathrm{~mm}^{2}$, Goodfellow Cambridge Ltd., thickness $0.125 \mathrm{~mm}$ ) were coated with carbon inks via a dropcast method. The vulcanized carbon/Pt ink was composed of $29 \mathrm{mg}$ of $19.7 \% \mathrm{Pt} /$ vulcanized carbon (DeNora North America, Pt on Vulcan XC-72), 2-propanol, water, and a 5\% Nafion binder. The ink $(30 \mu \mathrm{L})$ was applied with a micropipette and allowed to dry on the flag at $35^{\circ} \mathrm{C}$ for $8 \mathrm{~h}$. Once three coats were applied, the anode was attached to an $8 \mathrm{~cm}$ diameter polystyrene Petri dish with Devcon 5 min epoxy. A centrifuged pellet of DSP $10\left(10 \mathrm{~min}, 10^{\circ} \mathrm{C}, 4000 \mathrm{~g}\right)$ was then applied to the anode surface via a bacterial loop. A nanoporous membrane (either regenerated cellulose or polycarbonate) was then placed on top of the anode and sealed with Devcon 5 min epoxy. The cathode was placed on top of the membrane and attached with epoxy to the Petri dish. The fuel cell was then covered with aerobic $15 \mathrm{mM}$ sodium lactate in minimal medium (18). After the electrodes were connected with titanium wires, the whole device was placed on an orbital shaker set at $30 \mathrm{rpm}$ during data collection. The shaker was used to simulate natural motions in the water column and ensured aeration of the minimal medium.

Imaging of the Sterilization Filters. Environmental scanning electron microscopy (ESEM) of the membranes used in this paper was performed at the Naval Research Laboratory, Stennis Space Center, MS. After 1-2 min of gentle rinsing in distilled water, the membrane was removed and placed on the Peltier cooling device inside the ESEM chamber. The samples were kept wet by using the Peltier cooling device maintained at $4{ }^{\circ} \mathrm{C}$ and a chamber water vapor pressure between 4.5 and 5.5 Torr. Water vapor was allowed to condense on the cooled target to keep it moist while ESEM imaging was performed. Liquid water was removed from the top layer, several micrometers thick, to view the membranes.

Data Acquisition. The voltage across a load was measured by a personal data acquisition device (IO tech, personal daq/ 54) every $2 \mathrm{~min}$. The measured voltage was converted to current through Ohm's law (voltage $=$ current $\times$ resistance) and to power by use of power $=$ current $\times$ voltage. Voltage measurements for power curves were allowed to reach steady state ( $\sim 5 \mathrm{~min})$ and were performed in triplicate, with the average value reported.

\section{Results and Discussion}

Nanoporous Membranes as PEMs in a Mini-MFC. The general size-selective transport properties of the nanoporous filters [not including regenerated (reg) cellulose and Nafion] precluded the use of ferricyanide as a catholyte because of unimpeded crossover of the electrolyte into the anode chamber over time. Environmental scanning electron microscopy (ESEM) images of all membranes are shown in Figure 2. These images show qualitatively that the osmotic Nafion (pore size $<5 \mathrm{~nm}$ ) and regenerated cellulose (molecular weight contained $>12000-14000 \mathrm{kDa}$ ) membranes should behave similarly with regard to catholyte crossover in the mini-MFCs, while the nanoporous polycarbonate, nylon, and cellulose nitrate should not retain the electrolyte in the cathode because of their larger pore size $(200 \mathrm{~nm}$, or $40 \times$ larger than Nafion) and general topology. During the operation of the mini-MFC the polycarbonate, nylon, and cellulose nitrate membranes did not retain the catholyte in the cathode chamber. Complete crossover of the catholyte (dilution of the anolyte) was observed over the first $15 \mathrm{~h}$ of MFC operation with these membranes, while Nafion and 


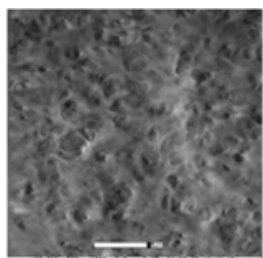

Nylon

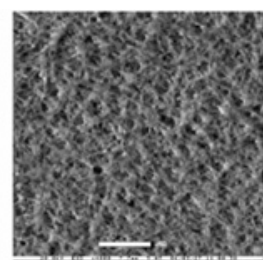

Cellulose Nitrate

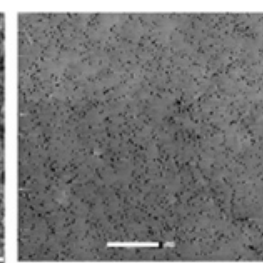

Polycarbonate

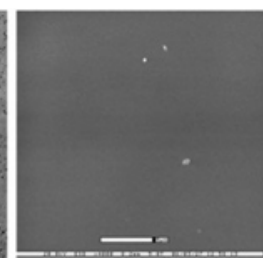

Reg. Cellulose

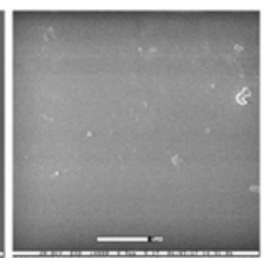

Nafion-117

FIGURE 2. ESEM images of nanoporous filters. All scale bars are $5 \mu \mathrm{m}$.

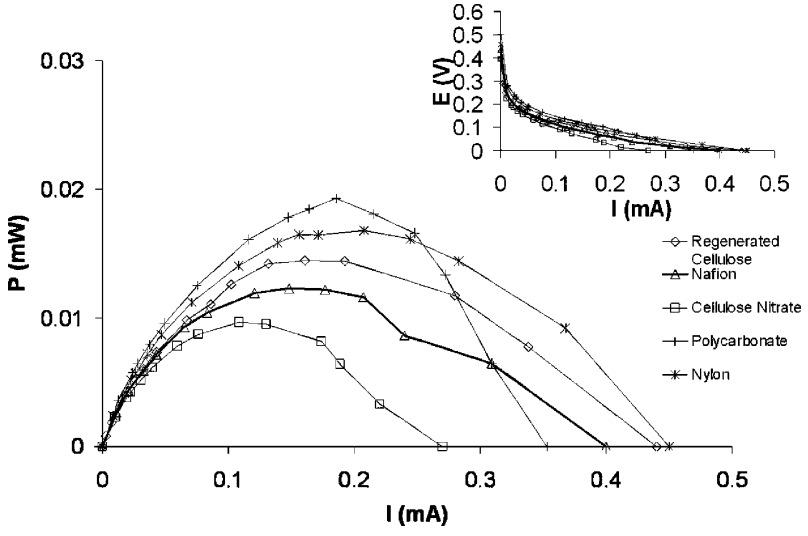

FIGURE 3. Effect of membrane composition on the voltage (inset) and power from a mini-MFC with uncoated GF oxygen reduction cathodes.

regenerated cellulose retained the bulk of the liquid in each chamber.

A two-chamber miniature MFC (mini-MFC) designed by Ringeisen et al. (17) was used initially to study these nanoporous polymer membranes in comparison to a Nafion PEM. The mini-MFC design enhances the surface area to volume ratio and minimizes the diffusion distance to the membrane when compared to many macroscopic MFCs (17), two concepts that are important in maximizing power density from a MFC. Aerobic cultures of Shewanella oneidensis DSP10 $\left(1 \times 10^{8}\right.$ cells $\left./ \mathrm{mL}\right)$ with no exogenous mediators were used as the anolyte for these experiments. As shown in Figure 3, the mini-MFC with Nafion-117 membranes produced a maximum power density of $11 \mathrm{~W} / \mathrm{m}^{3}$ (maximum power 13 $\mu \mathrm{W}$ ) when an uncoated graphite felt (GF) cathode for ORR was used (9). The power generated by use of all nanoporous membranes was comparable to that found when Nafion was used, ranging from $19 \mu \mathrm{W}\left(16 \mathrm{~W} / \mathrm{m}^{3}\right)$ for polycarbonate to $8 \mu \mathrm{W}\left(6 \mathrm{~W} / \mathrm{m}^{3}\right)$ for cellulose nitrate (Figure 3 ). The polarization curves (Figure 3, inset) for all experiments also have the same general profile, indicating that cation-selective membranes (Nafion) are not required to produce comparable voltage, current, and power in the mini-MFC.

Calculation of the internal resistance of all mini-MFCs running with each membrane was performed through linear fitting of the polarization data (Supporting Information, Figure S6). The internal resistance was calculated to be 550 $\pm 100 \Omega$, with no apparent trends observed with respect to the different membranes. The accuracy of this calculation is supported by the power curves shown in Figure 3, as the external resistance $(570-820 \Omega$ ) used to generate the maximum power for each membrane was similar to the calculated internal resistance (19). Based on the use of the same electrolytes and uncoated electrodes, the similar internal resistances indicate there are either minimal differences in membrane conductivity or low overall resistance of each membrane $(\ll 550 \Omega)$.

Several observations can be made from the data shown in Figure 3. First, the lowest power is measured when the

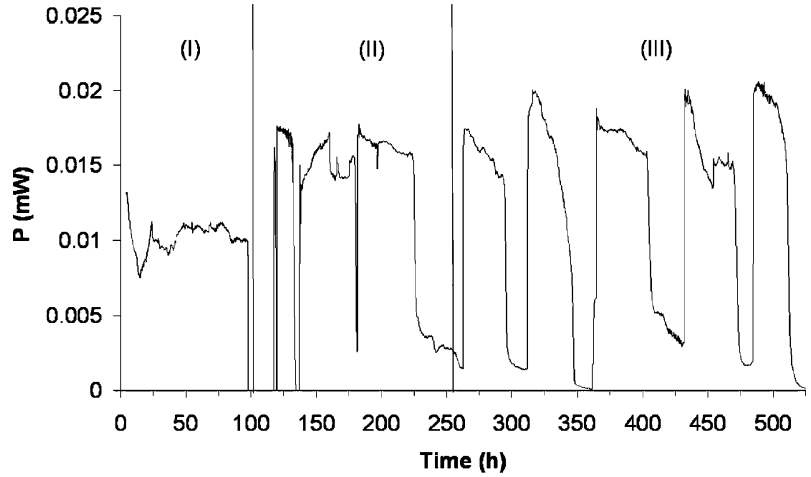

FIGURE 4. Power produced from a mini-MFC versus time by use of a polycarbonate membrane with uncoated bare GF cathode. (I) Initial operation with diluted anolyte; (II) new culture with $50 \mathrm{mM}$ sodium lactate; (III) addition of $30 \mathrm{mM}$ sodium lactate five times.

cellulose nitrate membrane is used $(9 \mu \mathrm{W})$. This reduced power is most likely due to poor durability, as the membrane began to physically degrade after less than $20 \mathrm{~h}$ of mini-MFC operation (Supporting Information, Figure S1). We found that the maximum power produced by the mini-MFC when nylon $(17 \mu \mathrm{W})$ and polycarbonate $(19 \mu \mathrm{W})$ membranes were used was significantly higher ( $30 \%$ and $50 \%$, respectively) than the power output achieved when Nafion was used (13 $\mu \mathrm{W}$ ). This power increase is most likely due to the open pore structure of the nylon and polycarbonate membranes, which enhance diffusion when compared to the osmotic nature of the regenerated cellulose and Nafion membranes. An order of magnitude increase in power output was achieved when the uncoated GF cathode was replaced with a Pt/C GF cathode (9) (Supporting Information, Figure S4; $170 \mu \mathrm{W}, 140 \mathrm{~W} / \mathrm{m}^{3}$ or $850 \mathrm{~mW} / \mathrm{m}^{2}$ ). This type of power increase is typical in MFCs when Pt-modified electrodes are used in place of unmodified graphite/carbon (20). In summary, the power density when nanoporous membranes are used $(45-95 \mathrm{~mW} /$ $\mathrm{m}^{2}, 2 \times 10^{-4} \mathrm{~m}^{2}$ mini-MFC cross-section) is on the same order of magnitude as the maximum value in the literature for pure cultures of Shewanella in a macroscopic MFC with a Nafion membrane and bare graphite (21) or mediatormodified electrodes $\left(10 \mathrm{~mW} / \mathrm{m}^{2}\right)(22)$. These results also indicate that the mini-MFC design continues to produce the highest power density for any MFC (per volume) when either Nafion $(9,17)$ or a range of polymeric nanoporous membranes are used.

The use of the polycarbonate membrane enabled over $500 \mathrm{~h}$ of continuous operation of the mini-MFC with little to no loss of power production (Figure 4). Seven separate additions of lactate to the anolyte resulted in seven distinct spikes in power output, indicating the metabolism of lactate by DSP10 was responsible for current production. The power versus time data for the polycarbonate membrane show a moderate decrease in power over the first $15 \mathrm{~h}$ of operation (time period I), which was due to an observed catholyte crossover through the polycarbonate membrane (anolyte dilution). The power rose slightly over the next $70 \mathrm{~h}$ as a result of modest bacterial growth in this high-salt solution. 


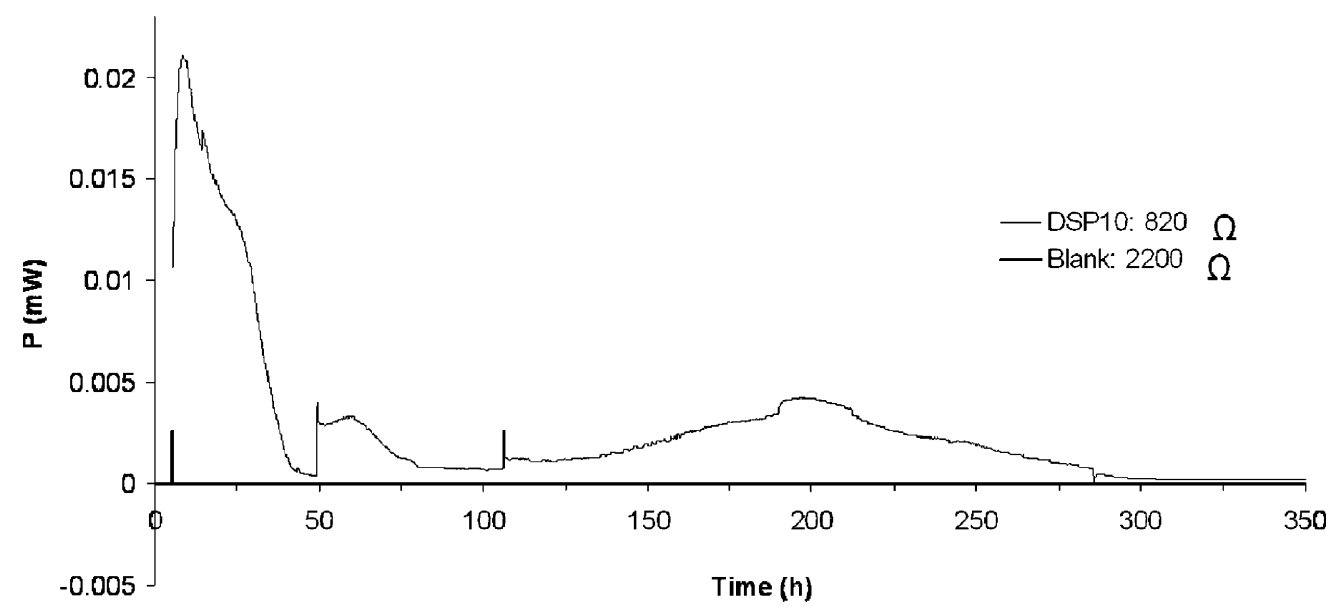

FIGURE 5. Power generated from the dialysis-tube MFC depicted in Figure 1a with and without DSP10 in the anode chamber at $25{ }^{\circ} \mathrm{C}$.

However, when the anode culture was replaced with a new (less than 4 days old) DSP10 culture, and the cathode was moistened (not submerged) periodically with deionized (DI) water, the power increased and stabilized over the next $150 \mathrm{~h}$ with the addition of $50 \mathrm{mM}$ lactate (time period II). The most promising aspect of using the polycarbonate membrane (unlike the regenerated cellulose and cellulose nitrate membranes) was that there was no loss in power from the fuel cell after periodic stimulation with $30 \mathrm{mM}$ lactate over the next $250 \mathrm{~h}$ (time period III). This same behavior was observed previously with Nafion-117 membranes over $300 \mathrm{~h}$ (17).

The high durability of these nanoporous membranes is essential if they are to be used as replacements for Nafion $(23,24)$. Membrane durability was probed by monitoring the power output from the mini-MFC for at least $500 \mathrm{~h}$. A representative power profile with time for one nanoporous membrane (polycarbonate) is shown in Figure 4, while the complete sets of time data for the cellulose nitrate, nylon, and regenerated cellulose membranes are provided in the Supporting Information (Supporting Information, Figures $\mathrm{S} 1-\mathrm{S} 3$ ). The best performing membranes, with respect to longevity, were the nylon (Supporting Information, Figure S2) or polycarbonate membranes. Contrary to this, it was concluded that the cellulose nitrate membrane was the least durable (MFC lasted <40 h; Supporting Information, Figure S1) and the regenerated cellulose membrane was structurally sound but maximum power could not be maintained during the latter half of operation (Supporting Information, Figure S3). These data suggest that the polyester and polyamide membranes were the most robust when used in the miniMFC.

Nanoporous Membranes Enabling “Chamberless" and "Pumpless" MFCs. The greatest impact of using nanoporous membranes is exhibited when new design concepts are considered. Many of the highest power densities reported for MFCs are achieved in flow reactor designs. However, the power necessary to maintain this flow is not normally subtracted from the overall power output of the MFC, as would be necessary in a real-world application. The passive diffusion of nutrients into a fuel cell system, rather than pumping, would alleviate the overall power needs of MFCs, thereby potentially increasing its time of deployment and efficiency by simplifying the system. By using nanoporous membranes rather than Nafion, we fabricated two independent chamberless and pumpless MFCs that could function in aerobic natural environments with an indigenous nutrient supply.

Dialysis-Tube MFC. The first alternative design using nanoporous membranes was a pumpless and chamberless device with a regenerated cellulose dialysis tube as the fuel cell membrane and foundation of the MFC (Figure 1a). By using a nanoporous membrane with an average pore size smaller than most bacteria, the design limits anode contamination and competition from environmental bacteria. In addition, wrapping the cathode around the anode reduces the overall oxygen flux into the anode (due to consumption of oxygen at the cathode via ORR), thereby increasing the potential power by decreasing electron scavenging side reactions with oxygen.

The power versus time curve for the dialysis-tube MFC is shown in Figure 5. Both a control (blank, no DSP10) and a DSP10 dialysis-tube experiment were performed, and the power generated by the DSP10 MFC was significantly higher at all time points than the blank control $(<10 \mathrm{nW}$, solid line overlapping time axis). The power from the DSP10 device was higher $(20 \mu \mathrm{W})$ within the first $30 \mathrm{~h}$ than at any other point of the experiment (average power $3 \mu \mathrm{W}, 0.6 \mathrm{~W} / \mathrm{m}^{3}$ ). This power boost at early times was most likely due to the elevated nutrients and cell concentrations inside the anode chamber initially. Both of these were at levels not sustainable during the remaining $750 \mathrm{~h}$ of diffusion-controlled operation (Supporting Information, Figure S5). In this design, the nutrients are supplied passively to the bacteria in the anode either through or around the surrounding GF cathode (pumpless). After the power dropped to less than $50 \mathrm{nW}$ because of opportunistic bacteria fouling the surrounding electrolyte, replacement of the medium re-established the $3 \mu \mathrm{W}$ power output after $300 \mathrm{~h}$ of operation. Once the fuel cell was dissembled, the bacteria were plated onto LB/agar plates from both the solutions surrounding the cathode and inside the anode tube. Serial dilution of the anolyte showed that only DSP10 were contained in the anode, while the outer cathode solution consisted primarily of environmental Bacillius sp. and not Shewanella as determined through plating and staining experiments. Considering that air was not actively excluded from this setup, these power values compare well with other micro-aerophilic MFC experiments $(12,21)$, but this is the first design that incorporates passive diffusion and chamberless operation within a miniature MFC design.

Micro-MFC. The second chamberless and pumpless design was significantly smaller (total estimated geometric anode volume $25 \mu \mathrm{L}$ ) and was fabricated by use of a polycarbonate membrane and titanium foil electrodes (Figure 1b). The experiment was started by submersing the microMFC in $15 \mathrm{mM}$ sodium lactate/minimal medium. The peak power generated from this device $(750 \mathrm{nW})$ was recorded during the first $5 \mathrm{~h}$ of the experiment (Figure 6) and then stabilized at $220 \mathrm{nW}$ for roughly $20 \mathrm{~h}$ before dropping off due to biofouling of the cathode. The power and voltage for the micro-MFC decreased dramatically within the first $5 \mathrm{~h}$, most 


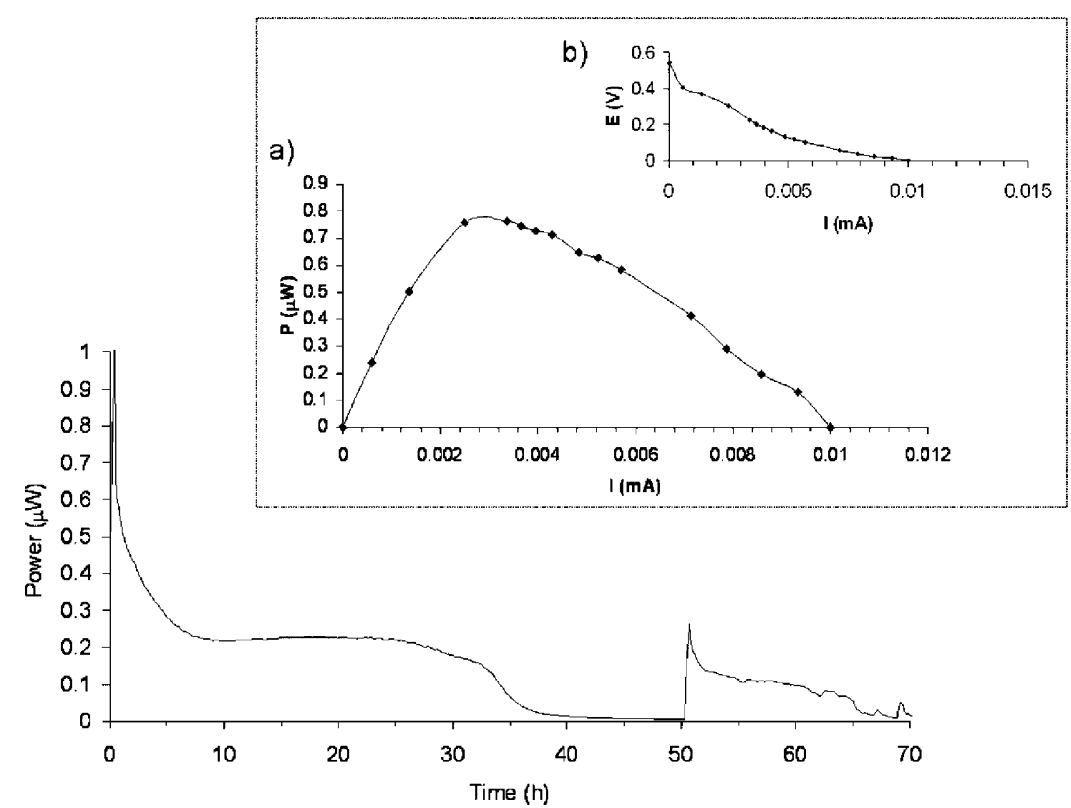

FIGURE 6. Power produced with time by use of a polycarbonate membrane within the micro-MFC design. Inset: (a) power versus current and (b) voltage versus current plots during the first $3 \mathrm{~h}$ of operation.

likely due to the inability to sustain the bacterial population on the available nutrients (diffusion through membrane). After a brief but vigorous agitation, the micro-MFC responded by showing sustained power above $100 \mathrm{nW}$ for an additional $15 \mathrm{~h}$. This was most likely due to complete or partial removal of the biofilm on the cathode surface. The power and polarization curves taken at $5 \mathrm{~h}$ are shown in the inset of Figure 6, demonstrating a maximum power of $750 \mathrm{nW}$ with a short circuit current of $10 \mu \mathrm{A}$ and an open circuit potential of $0.55 \mathrm{~V}$. The behavior of this MFC over time was identical to the power profile seen with the dialysis-tube MFC (Figure 5). The average power density of this crude, yet effective, chamberless micro-MFC during its entire operation was 10 $\mathrm{W} / \mathrm{m}^{3}$ and $6 \mathrm{~mW} / \mathrm{m}^{2}$ (electrode surface area). The highest reported power density $\left(0.3 \mathrm{~W} / \mathrm{m}^{3}\right)$ for a micro-MFC was reported by Chiao et al. (25) using two-dimensional electrodes, ferricyanide catholyte, Nafion membrane, and forced flow via a syringe pump. Our pumpless device utilized an ORR cathode rather than ferricyanide, yet produced 30 times the power density per volume with approximately the same cross-sectional area $\left(\sim 1.5 \mathrm{~cm}^{2}\right)$ used in the work of Chiao et al.

Role of Membranes in MFCs. Several recent papers indicate that MFC researchers are beginning to address the membrane's role in power production. Specifically, two groups have discussed the issues associated with use of Nafion membranes within MFCs. Rozendal et al. (26) highlighted the migration of cations other than protons across Nafion membranes electrochemically. Their work addressed the operational problems of using Nafion membranes in situations where other cations are present, concluding that only membranes that are $100 \%$ selective for protons will be ideal for use within MFCs. Zhao et al. (27) reported experiments where porphyrin-modified ORR cathodes were used with Nafion membranes. Their results suggest that $\mathrm{pH}$ gradients and enhanced cation transport at neutral $\mathrm{pH}$ across Nafion membranes can play a major role in reducing MFC efficiency. The use of nanoporous polycarbonate and polyester membranes will not establish a $\mathrm{pH}$ gradient between the chambers but will create an environment in the anode chamber that will be dictated by the bulk surrounding water and MFC design. This will increase the lifetime of the MFC as long as a micro-aerophilic environment can be established in the anode. It is clear from our work and the success of chamberless benthic devices that even though $\mathrm{pH}$ gradients will be established in a closed system between the cathode and anode chambers, an electrical disconnect along with the ability to sequester the bacteria around the anode are the only major requirements for generating current for a MFC.

Nafion appears to serve the same purpose as any general osmotic membrane under MFC conditions. The unique properties of proton-exchange membranes observed in standard PEMFC are muted at neutral $\mathrm{pH}$, at ambient temperatures, and in the presence of other salts. Due to its low oxygen permeability, Nafion does serves as an adequate membrane for biological fuel cells where strictly anaerobic conditions need to be maintained. However, nanoporous membranes within the unique passive diffusion designs described herein (pumpless delivery of nutrients through the cathode into the anode) makes it possible to fabricate a fuel cell that could be deployed with anaerobic bacteria in aerobic environments, similar to membrane-less MFCs where there is no Nafion and significant oxygen crossover to the anode chamber. However, membraneless MFCs are affected by contamination of the cathode by the microbe being used in the system and indigenous bacterial contamination (15). In addition, membraneless function decreases the overall efficiency of the MFC because electrons are donated to the anode and cathode simultaneously while oxygen concentrations at the cathode surface are decreased by biofilm formation. This work has shown that nanoporous membranes will prevent this type of cathode fouling with no apparent loss in power compared to Nafion. In addition to replacing Nafion, as demonstrated by the dialysis-tube MFC and the micro-MFC, these membranes can also be used as a way to isolate the desired bacteria at the anode and diversify the overall design and applications for biological fuel cells. The data presented here suggest that synthetic membranes like nylon and polycarbonate may serve as physically comparable but monetarily superior replacements (Nafion-117, \$0.22/ $\mathrm{cm}^{2}$, versus polycarbonate, $<\$ 0.02 / \mathrm{cm}^{2}$ ) for Nafion. Future investigations are necessary to determine whether similar benefits could be found in other biological fuel cells where fuel crossover is not detrimental to the power generated from the device. 


\section{Acknowledgments}

This work was funded by The Office of Naval Research (NRL 6.2 Program Element Number 62123N). We thank Dr. Jeremy Pietron for his help in developing the Pt/C ink for the cathode and the National Research Council for a research associateship for J.C.B.

\section{Supporting Information Available}

Additional data as referenced in the text (Figures S1-S6). This material is available free of charge via the Internet at http://pubs.acs.org.

\section{Literature Cited}

(1) Tender, L. M.; et al. Harnessing microbially generated power on the seafloor. Nat. Biotechnol. 2002, 20, 821-825.

(2) Shantaram, A.; Beyenal, H.; Veluchamy, R. R. A.; Lewandowski, Z. Wireless Sensors Powered by Microbial Fuel Cells. Environ. Sci. Technol. 2005, 39, 5037-5042.

(3) Cohen, R. Gemini fuel cell system. Proc. Annu. Power Sources Conf. 1966, 20, 21-24.

(4) Larminie, J.; Dicks, A. Fuel Cell Systems Explained, 2nd ed.; John Wiley \& Sons Ltd.: West Sussex, U.K., 2003.

(5) Bullen, R. A.; Arnot, T. C.; Lakeman, J. B.; Walsh, F. C. Biofuel cells and their development. Biosens. Bioelectron. 2006, 21, 2015-2045.

(6) Palmore, G. T. R.; Whitesides, G. M. Microbial and enzymic biofuel cells. ACS Symp. Ser. 1994, 566, 271-290.

(7) Chaudhuri, S. K.; Lovley, D. R. Electricity generation by direct oxidation of glucose in mediatorless microbial fuel cells. Nat. Biotechnol. 2003, 21, 1229-1232.

(8) Kim, B.-H.; Kim, H.-J.; Hyun, M.-S.; Park, D.-H. Direct electrode reaction of $\mathrm{Fe}(\mathrm{III})$-reducing bacterium, Shewanella putrefaciens. J. Microbiol. Biotechnol. 1999, 9, 127-131.

(9) Biffinger, J. C.; Pietron, J.; Ray, R.; Little, B.; Ringeisen, B. R. A Biofilm Enhanced Miniature Microbial Fuel Cell Using Shewanella oneidensis DSP10 and Oxygen Reduction Cathodes. Biosens. Bioelectron. 2006 (in press); http://dx.doi.org/10.1016/ j.bios.2006.1007.1027.

(10) Shukla, A. K.; Suresh, P.; Berchmans, S.; Rajendran, A. Biological fuel cells and their applications. Curr. Sci. 2004, 87, 455-468.

(11) Logan, B. E. Extracting hydrogen and electricity from renewable resources. Environ. Sci. Technol. 2004, 38, 160A-167A.

(12) Ringeisen, B. R.; Ray, R.; Little, B. A Miniature Microbial Fuel Cell Operating With an Aerobic Anode Chamber.J. Power Sources 2006, In Press.

(13) Nealson, K. H.; Belz, A.; McKee, B. Breathing metals as a way of life: geobiology in action. Antonie Van Leeuwenhoek 2002, $81,215-222$
(14) Liu, H.; Cheng, S.; Logan, B. E. Power Generation in Fed-Batch Microbial Fuel Cells as a Function of Ionic Strength, Temperature, and Reactor Configuration. Environ. Sci. Technol. 2005, 39, 5488-5493.

(15) Liu, H.; Logan, B. E. Electricity Generation Using an Air-Cathode Single Chamber Microbial Fuel Cell in the Presence and Absence of a Proton Exchange Membrane. Environ. Sci. Technol. 2004, 38, 4040-4046.

(16) Park, D. H.; Zeikus, J. G. Improved fuel cell and electrode designs for producing electricity from microbial degradation. Biotechnol. Bioeng. 2003, 81, 348-355.

(17) Ringeisen, B. R.; et al. High Power Density from a Miniature Microbial Fuel Cell Using Shewanella oneidensis DSP10. Environ. Sci. Technol. 2006, 40, 2629-2634.

(18) Myers, C. R.; Nealson, K. H. Bacterial manganese reduction and growth with manganese oxide as the sole electron acceptor. Science 1988, 240, 1319-1321.

(19) Logan, B. E.; Regan, J. M. Microbial fuel cells-challenges and applications. Environ. Sci. Technol. 2006, 40, 5172-5180.

(20) Oh, S.; Min, B.; Logan, B. E. Cathode Performance as a Factor in Electricity Generation in Microbial Fuel Cells. Environ. Sci. Technol. 2004, 38, 4900-4904.

(21) Kim, H. J. et al. A mediator-less microbial fuel cell using a metal reducing bacterium, Shewanella putrefaciens. Enzyme Microb. Technol. 2002, 30, 145-152.

(22) Park, D. H.; Zeikus, J. G. Impact of electrode composition on electricity generation in a single-compartment fuel cell using Shewanella putrefaciens. Appl. Microbiol. Biotechnol. 2002, 59 $58-61$.

(23) Mauritz, K. A.; Moore, R. B. State of understanding of Nafion. Chem. Rev. 2004, 104, 4535-4585.

(24) Banerjee, S.; Curtin, D. E. Nafion perfluorinated membranes in fuel cells. J. Fluorine Chem. 2004, 125, 1211-1216.

(25) Chiao, M.; Lam, K. B.; Lin, L. Micromachined microbial fuel cells. Proceedings - IEEE 16th Annual International Conference on Micro Electro Mechanical Systems, Kyoto, Japan, Jan 1923, 2003; pp 383-386.

(26) Rozendal, R. A.; Hamelers, H. V. M.; Buisman, C. J. N. Effects of Membrane Cation Transport on $\mathrm{pH}$ and Microbial Fuel Cell Performance. Environ. Sci. Technol. 2006, 40, 5206-5211.

(27) Zhao, F.; et al. Challanges and Constraints of Using Oxygen Cathodes in Microbial Fuel Cells. Environ. Sci. Technol. 2006, 40, 5193-5199.

Received for review July 10, 2006. Revised manuscript received December 6, 2006. Accepted December 11, 2006.

ES061634U 